\title{
IMPACTS OF CLIMATE VARIABILITY AND LAND-USE CHANGE ON HYDROLOGY IN THE PERIOD 1981-2009 IN THE CENTRAL HIGHLANDS OF VIETNAM
}

\author{
KHOI D.N. ${ }^{1,2, *}$, \\ THOM V.T. ${ }^{2}$
}

\author{
${ }^{1}$ Faculty of Environment, University of Science \\ Vietnam National University - Ho Chi Minh City \\ 227 Nguyen Van Cu Str., Dist. 5, Ho Chi Minh City, Vietnam \\ ${ }^{2}$ Center of Water Management and Climate Change \\ Vietnam National University - Ho Chi Minh City \\ IT Park, Linh Trung Ward, Thu Duc District \\ Ho Chi Minh City, Vietnam
}

Received: $16 / 06 / 2015$

Accepted: 28/11/2015

Available online: $16 / 12 / 2015$

*to whom all correspondence should be addressed: e-mail: dnkhoi86@gmail.com

\section{ABSTRACT}

In this study, we investigated the separate and combined impacts of climate and land-use changes on hydrological response in the Central Highlands of Vietnam during the period 1981-2009. The MannKendall and Pettit tests were applied to detect the trends in the hydro-meteorological data. The Soil and Water Assessment Tool (SWAT) was setup in the region, and evaluation based on daily data highlights the models adequacy. From this, the responses of hydrology to climate variability and land-use changes were considered. Overall, variability in climate seems to strongly drive the variability in the hydrological response in comparison to alternations in the hydrological regime due to land-use change during the period 1981-2009. The results indicate that land-use change had a minor impact on the annual flow $(0.4 \%$ reduction), whilst the impact from climate variability had been more significant (13.5\% change). Under the impact of coupled climate variability and land-use change, the annual streamflow increased by $13.1 \%$.

Keywords: climate variability; hydrology; land-use change; Srepok River Basin; SWAT model

\section{Introduction}

Water resources are currently under severe pressure because of impacts of climate change and human activities, which include land-use change, increasing population growth, and economic development (IPCC, 2013). Assessing water resources becomes a complex task that must consider many aspects, of which climate and land-use changes and variability are identified as key factors (Elfert and Bormann, 2010). As a consequence of climate change/variability, precipitation and temperature changes, which affect the hydrological cycle, and thus change the streamflow (Tu, 2009); whereas land-use change can cause changes in hydrological components in a basin, such as evapotranspiration, surface runoff, and groundwater. Thus, separating the effects of climate and land-use changes on hydrology is important to produce accurate predictions of streamflow and to provide useful information to land-use planning and water resources management (Pechlivanidis et al., 2011).

Studies on the impacts of climate and land-use changes on hydrology have been widely performed in different continents, e.g. among others, Europe (e.g. Wetterhall et al., 2011; Donnelly et al., 2014), Asia (e.g. Wang et al., 2008; Ma et al., 2009; Wang et al., 2013; Pechlivanidis et al., 2015), Africa (e.g. Mango et al., 2011; Bossa et al., 2014), America (e.g. Wang et al., 2014; Heo et al., 2015). The common methods 
can be classified into three groups, including paired catchments approach, statistical analysis approach, and hydrological modelling approach (e.g. Li et al., 2012). Among these approaches, the hydrological method is an appealing option because it is mostly suitable to be used as part of scenario studies on the relationships between climate, land-use, and hydrological components. In addition, regional impacts of climate and land-use changes on hydrology vary from place to place and need to be investigated on a local scale (e.g. Wang et al., 2013). For instance, impacts of land-use and climate changes on streamflow were conducted in the Johor River Basin (Malaysia) by Tan et al., (2015) and the result indicated that climate variability has stronger impacts than land-use change on streamflow. In addition, Zhang et al., (2013) investigated the similar study in the Fenhe River Basin (China) and they concluded that land-use change was the main driving factors for the decrease in streamflow.

In Vietnam, most studies have focused on the impact of climate changes on hydrology without considering land-use change as well (e.g. Phan et al., 2011; Raghavan et al., 2014). Others have only addressed the changes in hydrology with impact of land-use change (Ngo et al., 2015; Quyen et al., 2015). Furthermore, no studies considering both land-use change and climate variability have been performed in the Central Highlands of Vietnam. The overall objective of this study is to assess the impacts of climate variability and land-use change on hydrology in the Srepok River Basin in the Central Highlands of Vietnam. The specific objectives are: (1) to simulate hydrological responses to climate variability and land-use change and (2) to investigate the combined impact of climate and land-use changes on hydrology. This study provides important information that decision-makers will need in order to assist with water resources management in the Central Highlands of Vietnam under changing environmental conditions.

\section{Study area}

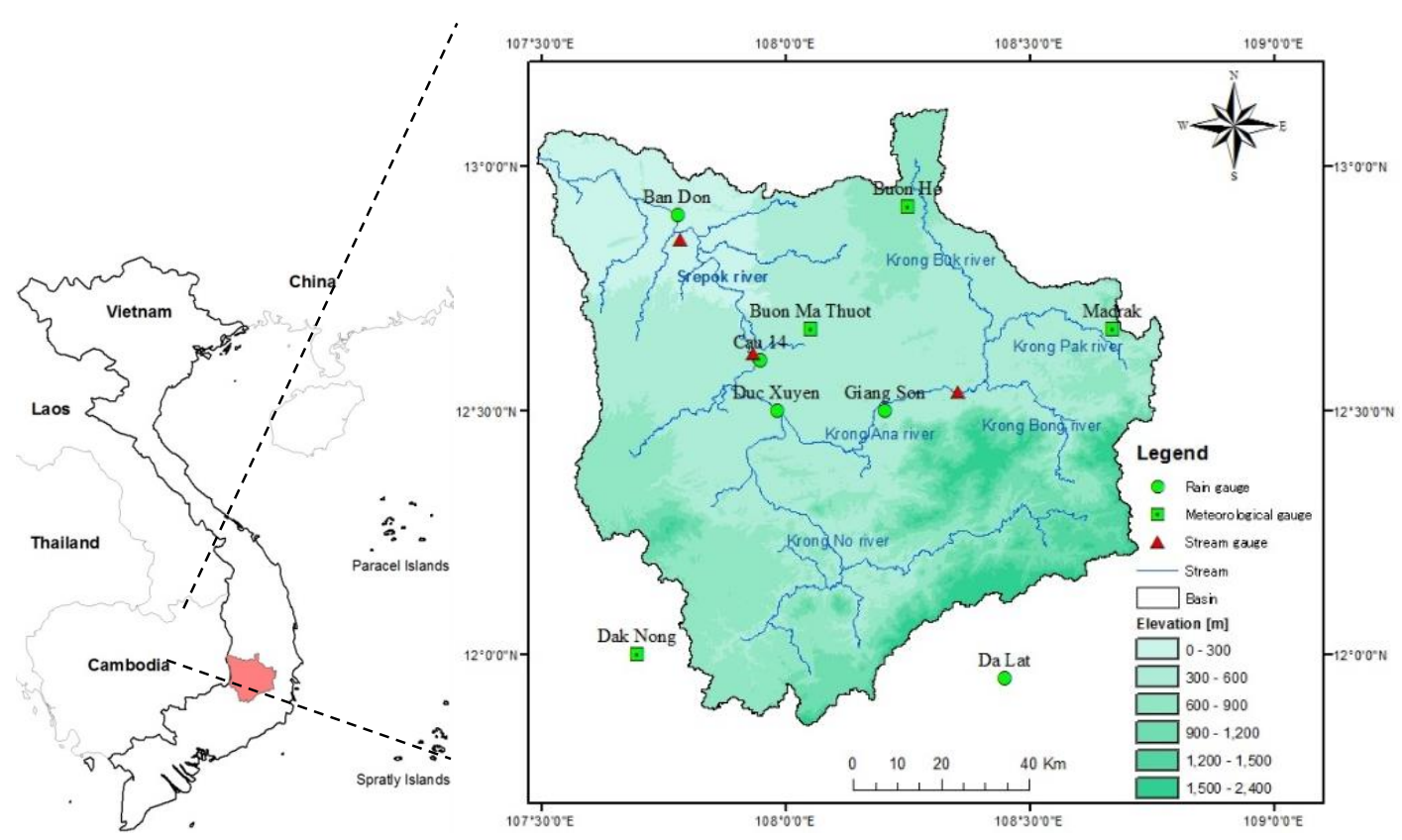

Figure 1. Location map of the Srepok River Basin

The Srepok River Basin, a sub-basin of the Mekong River Basin, is located in the Central Highlands of Vietnam, and lies between latitudes $11^{\circ} 45^{\prime}-13^{\circ} 15^{\prime} \mathrm{N}$ and longitudes $107^{\circ} 15^{\prime}-109^{\circ} \mathrm{E}$ (Fig. 1). The Srepok River is formed by two main tributaries: the Krong No and Krong Ana rivers. The total area of this basin is approximately $12,000 \mathrm{~km}^{2}$ with the population of 2.5 million in 2011 . The average altitude of the watershed varies from $100 \mathrm{~m}$ in the northwest to $2,400 \mathrm{~m}$ in the southeast. The climate in the area is very humid (78-83\% humidity) and annual rainfall varies from $1,700 \mathrm{~mm}$ to $2,300 \mathrm{~mm}$ and features a distinct wet and dry season. The wet season lasts from May to October (with peak floods often in September and 
October) and accounts for over $75-95 \%$ of the annual precipitation. The mean annual temperature is $23^{\circ} \mathrm{C}$. In this basin, there are two dominant soils: grey soils and red-brown basaltic soils. These soils are highly fertile consistent with the agricultural development in the study area. Agriculture is the main economic activity in this watershed of which coffee and rubber production are predominant. In total, five rain gauges and four meteorological stations are available (Fig. 1).

\section{Methodology}

\subsection{Change detection in hydro-meteorological data}

The Mann-Kendall test (Mann, 1945; Kendall, 1975), a non-parametric test, was used to identify the trends in hydro-meteorological time series. The Mann-Kendall test statistic is calculated as follows:

$$
Z_{c}=\left\{\begin{array}{cc}
\frac{S-1}{\sqrt{\operatorname{Var}(S)}} & S>0 \\
0 & S=0 \\
\frac{S+1}{\sqrt{\operatorname{Var}(S)}} & S<0
\end{array}\right.
$$

Where

$$
\begin{aligned}
& S=\sum_{i=1}^{n-1} \sum_{j=i+1}^{n} \operatorname{sgn}\left(x_{j}-x_{i}\right) \\
& \operatorname{sgn}\left(x_{j}-x_{i}\right)=\left\{\begin{array}{cc}
+1 & x_{j}-x_{i}>0 \\
0 & x_{j}-x_{i}=0 \\
-1 & x_{j}-x_{i}<0
\end{array}\right. \\
& \operatorname{Var}(S)=\frac{\left[n(n-1)(2 n+5)-\sum_{i=1}^{m} t_{i}\left(t_{i}-1\right)\left(2 t_{i}+5\right)\right]}{18}
\end{aligned}
$$

where $n$ is the length of the dataset, $x_{i}$ and $x_{j}$ are the sequential data values, $m$ is the number of tied groups (a tied group is a set of sample data with the same value), and $t$ is the number of data points in the $m^{\text {th }}$ group. The null hypothesis $H_{0}$ (there is no trend) is accepted if $-Z_{1-\alpha / 2} \leq Z_{c} \leq Z_{1-\alpha / 2}, \alpha$ is the significant level. A positive value of $Z_{c}$ indicates an increasing trend, and a negative value indicates a decreasing trend.

In the Mann-Kendall test, the Kendall slope is another very useful index that estimates the magnitude of the monotonic trend and is given by

$$
\beta=\operatorname{Median}\left(\frac{x_{j}-x_{i}}{j-i}\right), \forall i<j
$$

where $1<\mathrm{i}<\mathrm{j}<\mathrm{n}$. The estimator $\beta$ is calculated as the median of all slopes between data pairs for the entire dataset.

The changing point in the trend was further identified using the non-parametric Pettitt test (Pettitt, 1979). There are two samples $\left(x_{1}, x_{2}, \ldots, x_{t}\right)$ and $\left(x_{t+1}, x_{t+2}, \ldots, x_{N}\right)$ that come from the same population $\left(x_{1}, x_{2}, \ldots\right.$, $\left.x_{N}\right)$. The test statistic $U_{t, N}$ is given by

$$
U_{t, N}=\sum_{i=1}^{t} \sum_{j=t+1}^{N} \operatorname{sgn}\left(x_{i}-x_{j}\right)
$$


The null hypothesis of the Pettitt test is the absence of a change point. Its statistic $K_{t}$ and associated probabilities are given as

$$
\begin{aligned}
& K_{t}=\max \left|U_{t, N}\right| \\
& p=\exp \left(\frac{-6 K_{t}^{2}}{N^{3}+N^{2}}\right)
\end{aligned}
$$

When $p$ is smaller than the specific significance level, the null hypothesis is not accepted. The time $t$ when $\mathrm{K}_{\mathrm{t}}$ occurs is the change point time.

\subsection{SWAT hydrological model identification}

The SWAT model is a process-based distributed model designed to predict the impact of land management practices on water, sediment, and agricultural chemical yields in large complex watersheds with varying soil, land-use, and management conditions over long periods of time (e.g. Neitsch et al., 2011). With this model, a catchment is divided into a number of sub-watersheds or sub-basins. Sub-basins are further partitioned into hydrological response units (HRUs) based on soil types, land-use types, and slope classes that allow a high level of spatial detail simulation. Table 1 summarizes the input data used in the study. After data preparation, the model setup then performed the following four main steps: (i) watershed delineation, (ii) hydrologic response unit (HRU) definition, (iii) model run, and (iv) calibration and validation of the model (e.g. Fiseha et al., 2013).

Table 1. Data sources for the Srepok River Catchment

\begin{tabular}{cccc}
\hline Data type & Data description & Scale & Data sources \\
\hline Topography & $\begin{array}{c}\text { Digital Elevation Map (DEM) } \\
\text { Land-use classification such as } \\
\text { agricultural land, forest, and urban in } \\
1993 \text { and 2003 }\end{array}$ & $90 \mathrm{~m}$ & USGS-Hydro-SHEDS \\
Soil & Soil types and physical properties & $10 \mathrm{~km}$ & $\begin{array}{c}\text { Food and Agriculture Organization } \\
\text { (FAO) }\end{array}$ \\
Meteorology & $\begin{array}{c}\text { Daily precipitation, minimum and } \\
\text { maximum temperature }\end{array}$ & Daily & $\begin{array}{c}\text { Vietnam's Hydro-Meterological } \\
\text { Data Centre (HMDC); data from } \\
\text { five rain gauges and four weather } \\
\text { stations (Fig. 1) for the period } \\
\text { 1981-2009 }\end{array}$ \\
\hline
\end{tabular}

The Srepok River Basin was delineated and subdivided into 72 sub-catchments with a threshold area of 8,000 ha. The weather stations were assigned to each sub-catchments based on their proximity to centroids of the sub-catchments. The simulation was run first for the calibration period of 1981 to 1990 using the first year as a warm-up period to stabilize the model. In the last step in the modelling process, the SWAT model was calibrated with 10 years of discharge data (1981-1990) and validated from 1991 to 1995 at the Giang Son, Cau 14, and Ban Don stations using Sequential Uncertainty Fitting (SUFI-2), which is implemented in the SWAT-CUP 2012 (Abbaspour, 2014). The discharge data were obtained from the Hydro-Meteorological Data Centre in Vietnam.

The Nash-Sutcliffe efficiency (NSE), percent bias (PBIAS), and ratio of root mean square error to the standard deviation of measured data (RSR) were used as statistical indices to assess the model performance. According to Moriasi et al., (2007), the values of NSE greater than 0.5, the PBIAS values less than $25 \%$, and the values of RSR less than 0.7 indicate a satisfactory model performance for flow simulation. 


\subsection{Impacts from climate variability and land-use change}

To investigate the separate and combined impact of climate and land-use changes on hydrological processes, the approach of one factor at a time while keeping others constant was used (Khoi and Suetsugi, 2014; Tan et al., 2015). The change point of precipitation is selected as the change point in climate data because rainfall plays a key role in hydrology and constitutes the most fundamental meteorological variable on the catchment scale. Meteorological data were divided into two periods, 1981-1995 (representing the 1980s) and 1996-2009 (representing 2000s), based on the change point analysis, and each period included one land-use map. The land-use map for 1993 was used to represent the 1980s, and the land-use map for 2003 was used to represent the 2000s. The following four scenarios were investigated:

Scenario 1 (Baseline): Land-use in 1993 and climate data for the 1980s.

Scenario 2 (Climate change): Land-use in 1993 and climate data for the 2000s.

Scenario 3 (Land-use change): Land-use in 2003 and climate data for the 1980s.

Scenario 4 (Climate and land-use change): Land-use in 2003 and climate data for the 2000s.

Four scenarios were used to run the well-calibrated SWAT model, and their outputs were compared to investigate the separate and combined impacts of land-use change and climate variability on hydrological processes.

\section{Results and discussion}

\subsection{Analysis of land-use changes - Observations}

The major land-use types in the Srepok River Basin were agricultural land and forest (Fig. 2 and Table 2), which accounted for $28.11 \%$ and $65.13 \%$ in 1993 and $21.84 \%$ and $59.88 \%$ in 2003 , respectively.
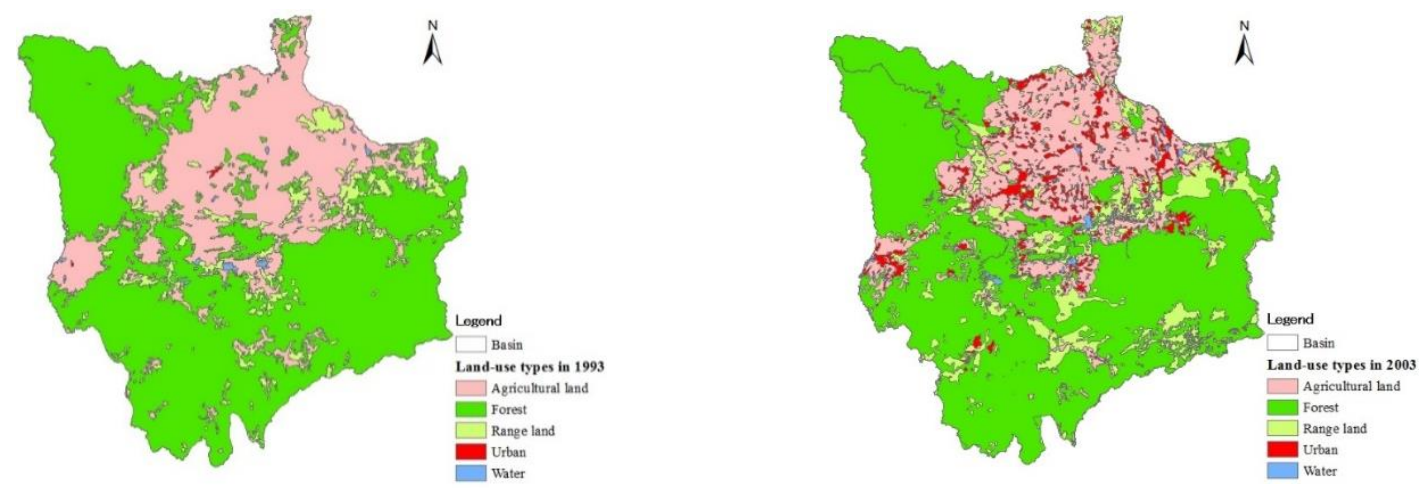

Figure 2. Land-use types of the Srepok River Basin in 1993 and 2003

Table 2. Statistics for land-use changes in the Srepok River Basin for the period $1993-2003$

\begin{tabular}{lcccccc}
\hline \multirow{2}{*}{ Land-use types } & \multicolumn{2}{c}{1993} & \multicolumn{2}{c}{$\mathbf{2 0 0 3}$} & \multicolumn{2}{c}{ Change } \\
\cline { 2 - 7 } & $\mathrm{Km}^{2}$ & $\%$ & $\mathrm{Km}^{2}$ & $\%$ & $\mathrm{Km}^{2}$ & $\%$ \\
\hline Agricultural land & 3,373 & 28.11 & 2,621 & 21.84 & -752 & -6.27 \\
\hline Range land & 754 & 6.28 & 1,403 & 11.69 & 649 & 5.41 \\
\hline Forest & 7,815 & 65.13 & 7,185 & 59.88 & -630 & -5.25 \\
\hline Urban & 6 & 0.05 & 661 & 5.51 & 655 & 5.46 \\
\hline Water & 52 & 0.43 & 130 & 1.08 & 78 & 0.65 \\
\hline Total & 12,000 & 100 & 12,000 & 100 & & \\
\hline
\end{tabular}


Generally, there were three main trends of land-use change: the decrease in the forest (deforestation), the increase in urban land, and agricultural land loss. Compared with 1993, the forest decreased by 5.25\%, urban land increased by $5.46 \%$, and agricultural land decreased by $6.27 \%$ of the basin area. Aside from this, there were slight increases in the range land $(5.41 \%)$ and water $(0.65 \%)$. The changes were caused by a population increase (which led to the expansion of settlements), rural industrialization (which led to the decreased agricultural land), and ineffective forest management (which led to excessive forest exploitation).

\subsection{Analysis of hydro-meteorological trend-Observations}

Annual temperature, precipitation, and streamflow were tested using the Mann-Kendall and Pettitt methods. The results are reported in Table 3 and are illustrated in Fig. 3.

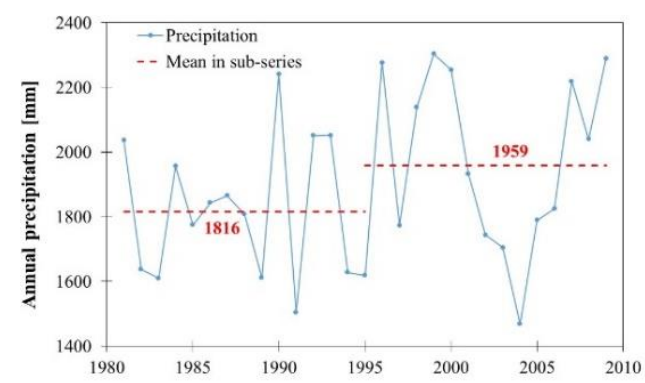

(a)

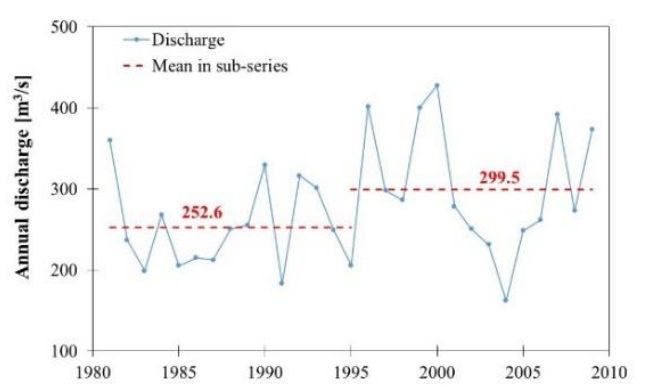

(c)

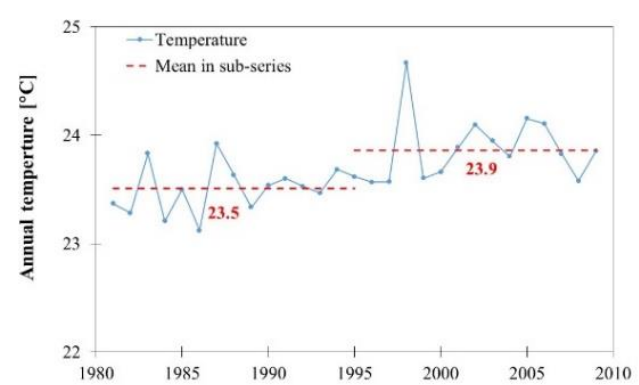

(b)

Figure 3. The variations of mean values in (a) annual precipitation, (b) annual temperature, and (c) annual discharge in the Srepok River Basin (1981-2009)

Table 3. Summary of Mann-Kendall trend test and Pettitt test for annual and seasonal rainfall, temperature and streamflow in the Srepok River Basin.

\begin{tabular}{llcccccc}
\hline & & \multicolumn{3}{c}{ Mann-Kendall test } & \multicolumn{3}{c}{ Pettitt test } \\
\cline { 2 - 7 } Precipitation & $\mathrm{Z}_{\mathrm{c}}$ & $\mathrm{B}$ & $\mathrm{p}$ & $\mathrm{K}_{\mathrm{T}}$ & $\mathrm{t}$ & $\mathrm{p}$ \\
\hline \multirow{3}{*}{ Temperature } & Annual & 0.167 & 8.438 & $*$ & 76 & 1995 & $*$ \\
& Dry season & 0.089 & 0.453 & $*$ & 80 & 1995 & $*$ \\
& Wet season & 0.103 & 0.534 & $*$ & 54 & 1995 & $*$ \\
\hline \multirow{3}{*}{ Streamflow } & Annual & 0.252 & 0.016 & $*$ & 99 & 1990 & $*$ \\
& Dry season & 0.314 & 0.033 & $* *$ & 138 & 1990 & $*$ \\
& Wet season & 0.035 & 0.02 & $*$ & 45 & 1986 & $*$ \\
\hline & Annual & 0.172 & 2.298 & $*$ & 92 & 1995 & $*$ \\
& Dry season & 0.148 & 1.009 & & 84 & 1995 & \\
& Wet season & 0.187 & 3.202 & $*$ & 82 & 1995 & \\
\hline
\end{tabular}

$\left({ }^{*}\right)$ Significance level at $p<0.1 ;(* *)$ Significance level at $p<0.05$ 
The results show rises in annual temperature, precipitation, and streamflow (by $0.016{ }^{\circ} \mathrm{C} \mathrm{yr}^{-1}, 8.438$ $\mathrm{mm} \mathrm{yr}^{-1}$, and $2.298 \mathrm{~m}^{3} \mathrm{~s}^{-1}$ year $^{-1}$ ) at $10 \%$ significance level. In other words, the null hypothesis $\mathrm{H}_{0}$ was not accepted by the annual temperature, rainfall, and streamflow time series. Change points in the annual rainfall and streamflow were detected as occurring around 1995 with a significance level of 10\%, while the change point in annual temperature was statistically significant in 1990 . The trend analysis was further conducted at the seasonal scale as shown in Table 3. Our trend analysis suggests that the Srepok River Basin gets warmer and wetter. A similar trend was reported by MONRE (2012) for the Central Highlands of Vietnam.

\subsection{SWAT model identification}

Sensitivity analysis is important to help identify the parameters most significantly influencing the model output. The sensitivity analysis was done for the whole basin using the SUFI-2 method. Twenty-seven hydrological parameters were utilized in the sensitivity analysis for the simulation of streamflow in the study area. The most sensitive parameter was found to be a curve number (CN2), followed by the channel effective hydraulic conductivity (CH_K2), the surface runoff lag time (SURLAG), the Manning's value for main channel ( $\left.\mathrm{CH}_{-} \mathrm{N} 2\right)$, and the baseflow alpha factor (ALPHA_BF). These sensitivity parameters were used for calibrating and validating the simulated streamflow (Table 4). The calibration and validation of the SWAT model for the Srepok River Basin were carried out by comparing the simulated streamflow with the observed flow at three gauging stations, including the Giang Son, Cau 14, and Ban Don stations. The daily streamflow for the period 1982-1995 and the land-use map for 1993 were used for the model calibration and validation.

Table 4. SWAT calibrated values for flow simulation

\begin{tabular}{|c|c|c|c|}
\hline Parameter & Description of parameter & Range & Calibrated value \\
\hline ALPHA_BF ${ }^{1}$ & Baseflow alpha factor & $0 \sim 1$ & 0.15 \\
\hline $\mathrm{CH} \_\mathrm{K} 2^{\overline{1}}$ & $\begin{array}{l}\text { Channel effective hydraulic } \\
\text { conductivity }\end{array}$ & $-100 \sim 100$ & 2.00 \\
\hline $\mathrm{CH} \_\mathrm{N} 2^{1}$ & Manning's $\mathrm{n}$ value for main channel & $0 \sim 0.3$ & 0.21 \\
\hline $\mathrm{CN} 2^{2}$ & Initial SCS CN II value & $-0.25 \sim 0.25$ & -0.03 \\
\hline SURLAG ${ }^{1}$ & Surface runoff lag time & $0 \sim 1$ & 0.07 \\
\hline
\end{tabular}

The plots of observed and simulated daily flow are presented in Fig. 4. It shows that the model could closely match the observation during the calibration and validation periods. However, the peak streamflow was not well matched, probably due to uneven representation of the spatial distribution of rainfall. The statistical indicators for evaluation of the model performance computed using daily streamflow in the calibration and validation periods are listed in Table 5, with the overall results highlighting the adequate model performance.

Table 5. Model performance for the simulation of streamflow

\begin{tabular}{ccccccc}
\hline & \multicolumn{3}{c}{ Calibration (1982-1989) } & \multicolumn{3}{c}{ Validation (1990-1995) } \\
\cline { 2 - 7 } & NSE & PBIAS & RSR & NSE & PBIAS & RSR \\
\hline Giang Son & 0.71 & $11 \%$ & 0.53 & 0.64 & $6 \%$ & 0.60 \\
Cau 14 & 0.74 & $4 \%$ & 0.51 & 0.79 & $7 \%$ & 0.45 \\
Ban Don & 0.75 & $4 \%$ & 0.50 & 0.85 & $4 \%$ & 0.39 \\
\hline
\end{tabular}

\subsection{Hydrological responses to climate variability}

In order to investigate the impact of climate variability on hydrological processes, the simulation was carried out by using the land-use conditions of the 1993 and the climate data of two different periods: 1982-1995 (1980s) and 1996-2009 (2000s). Fig. 5 shows the absolute changes in the monthly climate variables between the two periods. Compared with the 1980s, the annual temperature increased by 
$0.40{ }^{\circ} \mathrm{C}$ and the annual precipitation increased by $166.9 \mathrm{~mm}(9.2 \%)$. The increases in temperature and precipitation were higher in the dry season $\left(0.42^{\circ} \mathrm{C}\right.$ and $\left.40.5 \%\right)$ than in the wet season $\left(0.37^{\circ} \mathrm{C}\right.$ and $\left.2.9 \%\right)$.

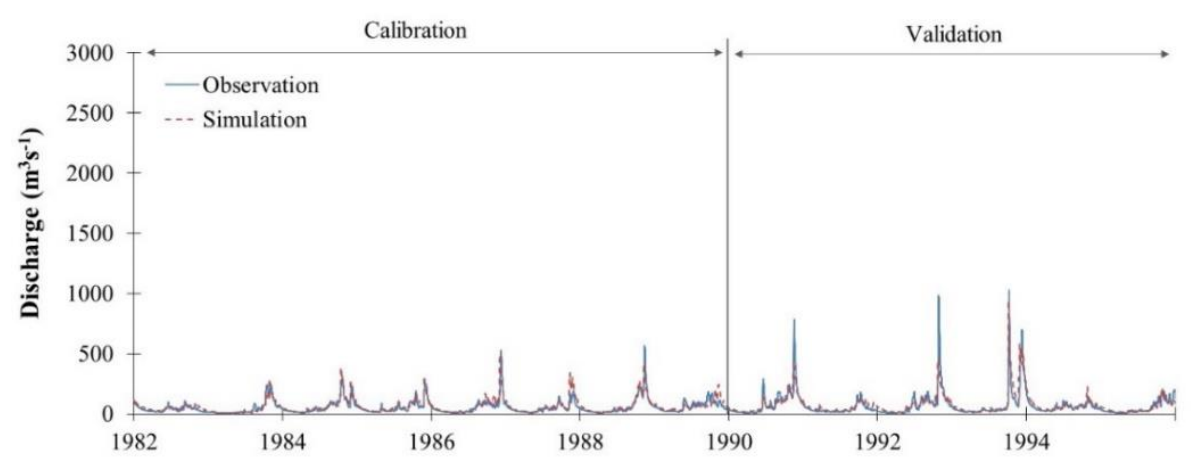

(a) Giang Son station

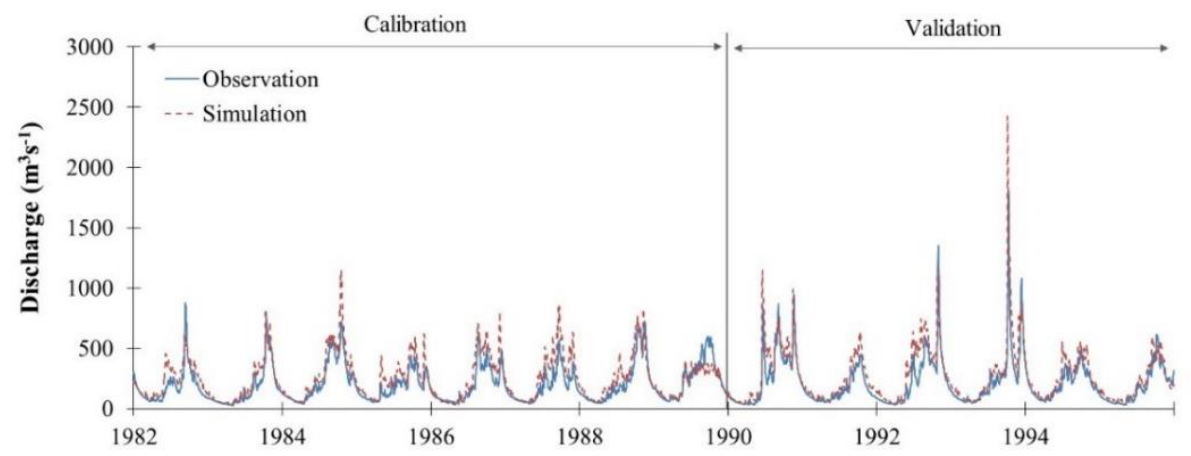

(b) Cau 14 station

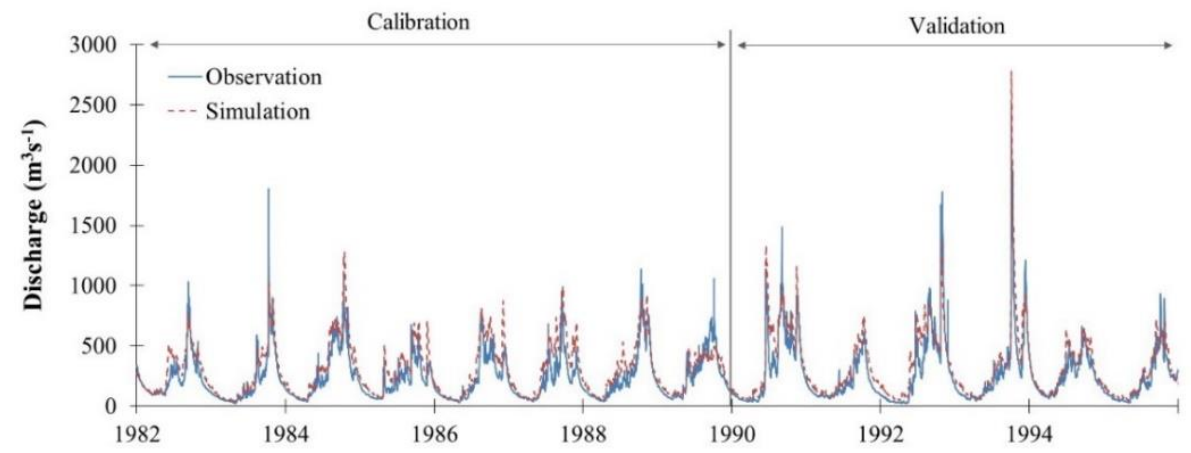

(c) Ban Don station

Figure 4. Observed and simulated streamflow during the calibration (1982-1989) and validation (1990-1995) periods

As shown in Fig. 6, climate change caused increases in all water balance components, including a $6.2 \%$ increase in actual evapotranspiration, a $5.8 \%$ increase in groundwater discharge, a $17.2 \%$ increase in surface runoff, a $7.4 \%$ increase in water percolation, a $9.1 \%$ increase in lateral flow, and a $5.1 \%$ increase in soil water content. These increases could be a result of increases in temperature and precipitation in the 2000s compared with those in the 1980s. The rise of temperature increases the evaporation rate, whereas the increase in precipitation enhances the runoff. Generally, the pattern of changes in water cycle is mainly determined by the changes in precipitation and temperature, which is similar to the finding 
of the studies on impact of climate change on hydrology in the Cau River Catchment (Northern of Vietnam) conducted by Phan et al., (2011), in the Be River Catchment (South of Vietnam) carried out by Khoi and Suetsugi (2014), and in the Johor River Basin (Malaysia) conducted by Tan et al., (2015).

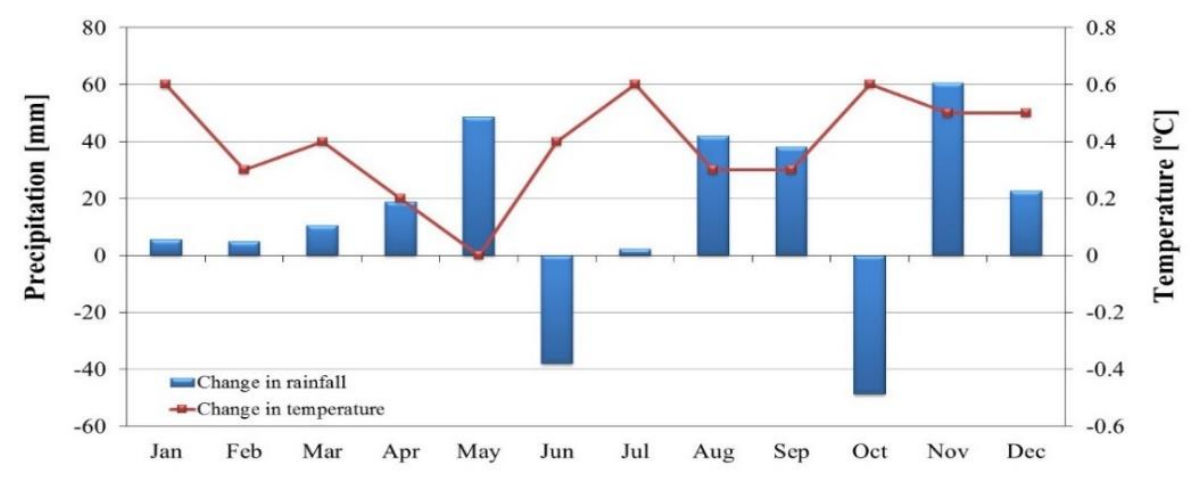

Figure 5. Monthly precipitation and temperature differences between the 1980s and 2000s in the Srepok River Basin

Under the impact of climate change, the annual streamflow increased by $13.5 \%$ (Fig. 7). The increase in flow can be explained by increases in precipitation and runoff in the 2000s compared with the 1980s. Considering the seasonal change, the streamflow increased significantly by $9.0 \%$ in the wet season and $27.4 \%$ in the dry season.

\subsection{Hydrological responses to land-use change}

The impact of the land-use change on water balance components is illustrated in Fig. 6 . Under the impact of the land-use change, actual evapotranspiration, lateral flow and runoff increased slightly by $0.57 \%$, $0.39 \%$, and $0.18 \%$, respectively. Aside from this, the other water balance components decreased including a $1.18 \%$ decrease in the groundwater discharge, a $0.51 \%$ decrease in the soil water content, a $1.06 \%$ decrease in the amount of water percolating out of the root zone, and a $0.33 \%$ decrease in the water yield. Deforestation, urbanization, and agricultural loss could be the cause of these changes. This is because forest vegetation intercepts and loses more water through evapotranspiration than other land-use types and the infiltration rate of forest land is largest compared with the other land-use types. Accordingly, deforestation and urbanization in the Srepok River Basin caused increases in evapotranspiration and runoff, and decreases in groundwater discharge, water percolation, and lateral flow.

Under the impact of land-use change, deforestation, urbanization, and the decrease in agricultural land resulted in a slight decrease in annual streamflow (0.4\%). Considering the seasonal change, the streamflow decreased by $1.3 \%$ in the dry season and by $0.1 \%$ in the wet season.

\subsection{Hydrological responses to combined climate variability and land-use change}

To investigate the combined impact of climate and land-use changes, the simulated streamflow, and water balance components under scenario 4 (land-use in 2003 and climate data in the 2000s) were compared to those during the baseline period (land-use in 1993 and climate data in the 1990s). The results are displayed in Fig. 6 and Fig. 7.

The combined impact of land-use change and climate variability caused increases in streamflow as well as all water balance components. When the directions of the changes affected by climate change alone and land-use change alone are opposite, the change is reduced when climate and land-use changes occur concurrently. On the other hand, when the changes caused by climate change alone and land-use change alone occur in the same direction, the change is intensified as climate change and land-use change occur simultaneously.

Table 6 shows the details of the annual streamflow simulated by the SWAT model under the different climate and land-use changes. 


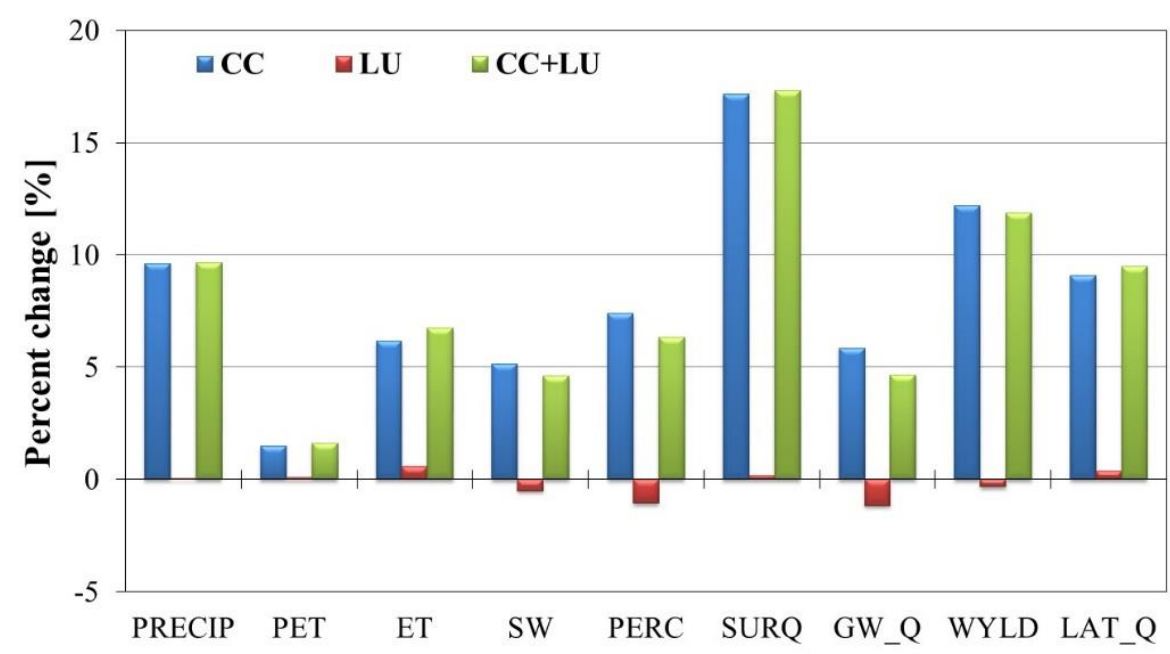

Figure 6. Annual changes of hydrological components under the impact of climate and land-use changes

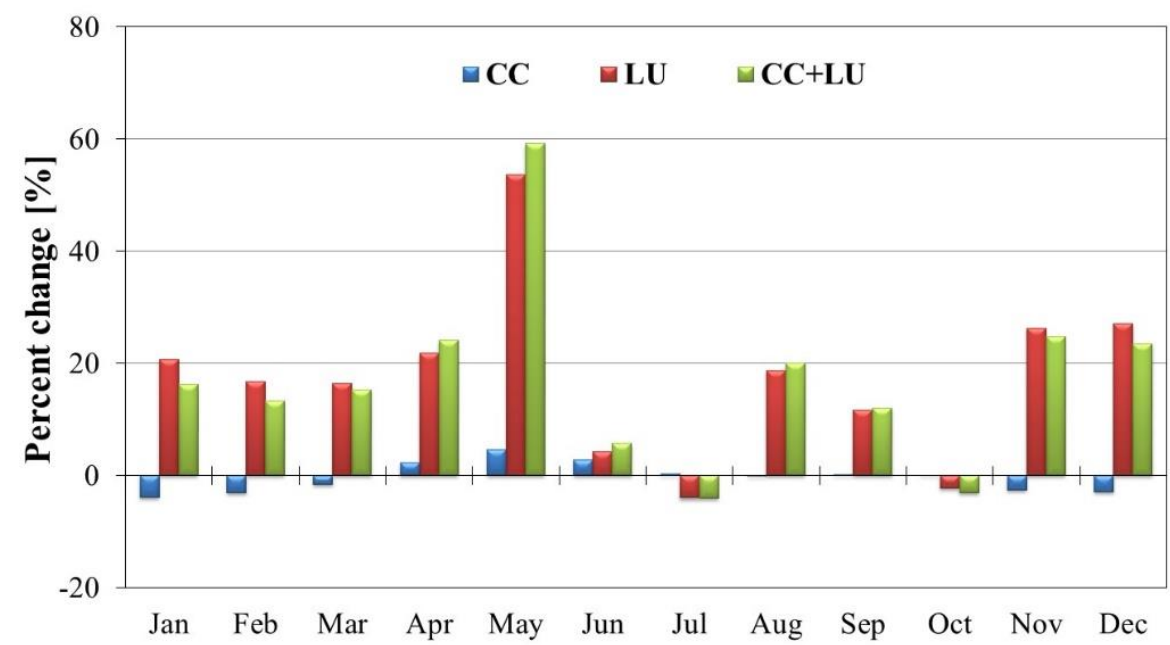

Figure 7. Monthly simulated streamflow under the impacts of climate and land-use changes at the Ban Don station

Table 6. Annual simulated streamflow under the impacts of climate and land-use changes at gauging stations

\begin{tabular}{cccccccccc}
\hline \multirow{2}{*}{ Scenario } & \multirow{2}{*}{$\begin{array}{c}\text { Land- } \\
\text { use }\end{array}$} & Climate & \multicolumn{2}{c}{ Ban Don } & \multicolumn{2}{c}{ Cau 14 } & \multicolumn{2}{c}{ Giang Son } \\
\cline { 4 - 8 } & & $\mathbf{m}^{\mathbf{3}} \mathbf{s}^{-\mathbf{1}}$ & $\begin{array}{c}\text { Change } \\
\mathbf{( \% )}\end{array}$ & $\mathbf{m}^{3} \mathbf{s}^{-\mathbf{1}}$ & $\begin{array}{c}\text { Change } \\
\text { (\%) }\end{array}$ & $\mathbf{m}^{\mathbf{3}} \mathbf{s}^{-\mathbf{1}}$ & $\begin{array}{c}\text { Change } \\
\text { (\%) }\end{array}$ \\
\hline 1 & 1993 & $1980 \mathrm{~s}$ & 308.8 & - & 257.7 & - & 66.5 & - \\
2 & 1993 & $2000 \mathrm{~s}$ & 350.4 & 13.5 & 298.2 & 15.7 & 89.4 & 34.4 \\
3 & 2003 & $1980 \mathrm{~s}$ & 307.7 & -0.4 & 256.7 & -0.4 & 66.4 & -0.2 \\
4 & 2003 & $2000 \mathrm{~s}$ & 349.3 & 13.1 & 297.2 & 15.3 & 89.3 & 34.3 \\
\hline
\end{tabular}

Compared with Scenario 1, the simulated streamflow in Scenario 4 increased by $349.3 \mathrm{~m}^{3} \mathrm{~s}^{-1}(13.1 \%)$, $297.2 \mathrm{~m}^{3} \mathrm{~s}^{-1}(15.3 \%)$, and $89.3 \mathrm{~m}^{3} \mathrm{~s}^{-1}(34.3 \%)$ for the Ban Don, Cau 14, and Giang Son stations, respectively; which represented the combined impacts of climate and land-use changes. Aside from this, the simulation results showed that percentage of contribution were $-0.4 \%,-0.4 \%$, and $-0.2 \%$ for the land-use change and $13.5 \%, 15.7 \%$, and $34.4 \%$ for the climate change in the Ban Don, Cau 14, and Giang Son stations, respectively. 
In general, the simulation results showed that the hydrological processes have stronger responses to climate variability compared to land-use change. This finding is similar to that reported by Tan et al., (2015) who did a similar study in the Johor River Basin (Malaysia) in the period 1975-2007.

\section{Conclusions}

The SWAT model was setup for the Srepok River Basin to simulate the impacts of climate variability and land-use change on the hydrological processes from 1981 to 2009. Climate variability in this study led to significantly increased streamflow and water balance components in the 2000 s compared to the $1980 \mathrm{~s}$. Increases in temperature and precipitation caused these increases in the course of the period. The landuse change in the study area caused decreases in streamflow, groundwater discharge, and soil water. These changes are attributed to deforestation, urbanization, and agricultural losses that happened in the 2000s. Under the impact of combined land-use and climate changes, the streamflow and water balance components increased in the 2000 s compared with those in the 1980s. In general, climate variability influenced hydrological processes more strongly than the land-use change in the basin during the period 1981-2009. Therefore, when planning and managing for water resources, the importance of increasing adaptation to climate change is emphasized.

\section{Acknowledgement}

This research is funded by Vietnam National Foundation for Science and Technology Development (NAFOSTED) under grant number "105.06-2013.09" and by Vietnam National University Ho Chi Minh City (VNU-HCM) under grant number “C2014-18-18".

\section{References}

Abbaspour K.C. (2014), SWAT-CUP 2012: SWAT Calibration and Uncertainty Programs - A User Manual, Swiss Federal Institute of Aquatic Science and Technology.

Bossa A.Y., Diekkruger B. and Agbossou E.K. (2014), Scenario-based impacts of land use and climate change on land and water degradation from the meso to regional scale, Water, 6, 3152-3181.

Donnelly C., Yang W. and Dahné J. (2014), River discharge to the Baltic Sea in a future climate, Climatic Change, 122, 157-170, doi:10.1007/s10584-013-0941-y.

Elfert S. and Bormann H. (2010), Simulated impact of past and possible future land use changes on the hydrological response of Northern German lowland 'Hunte' catchment, Journal of Hydrology, 383, 245-255.

Fiseha B.M., Setegn S.G., Melesse A.M., Volpi E. and Fiori A. (2013), Hydrological analysis of the Upper Tiber River Basin, Central Italy: a watershed modelling approach, Hydrological Processes ,27(16), 2339-2351.

Heo J., Yu J., Giardino J.R. and Cho H. (2015), Impacts of climate and land-cover changes on water resources in a humid subtropical watershed: a case study from East Texas, USA, Water and Environment Journal, 29(1), 51-60.

IPCC (2013), The Physical Science Basis: Contribution of working group I to the fifth assessment report of Intergovernmental Panel on climate change. - Cambridge University Press; Cambridge, UK and New York, NY.

Kendall M.G. (1975), Rank correlation Measures. - Charles Griffin, London.

Khoi D.N. and Suetsugi T. (2014), Impact of climate and land-use changes on hydrological processes and sediment yield - a case study of the Be River Catchment, Vietnam, Hydrological Sciences Journal, 59(5), 1095-1108.

Li H., Zhang Y., Vaze J. and Wang B. (2012), Separating effects of vegetation change and climate variability using hydrological modelling and sensitivity-based approaches, Journal of Hydrology, 420-421, 403-418.

Ma X., Xu J., Luo Y., Aggarwal S.P. and Li J. (2009), Response of hydrological processes to land-cover and climate changes in Kejie watershed, south-west China, Hydrological Processes, 23, 1179-1191.

Mango L.M., Melesse A.M., McClain M.E., Gann D. and Setegn S.G. (2011), Land-use and climate change impacts on hydrology of the upper Mara River Basin, Kenya: results of a modelling study to support better resources management, Hydrology and Earth System Sciences, 15, 2245-2258. 
Mann H.B. (1945), Non-parametric tests against trend, Econometrica, 13, 245-259.

MONRE (2012), Climate change, sea level rise scenarios for Vietnam.

Moriasi D.N., Arnold J.G., Van Liew M.W., Bingner R.L., Harmel R.D. and Veith T.L. (2007), Model evaluation guidelines for systematic quantification of accuracy in watershed simulations, Transactions of the ASABE, 50, 885-900.

Neitsch A.L., Arnold J.G., Kiniry J.R. and Williams J.R. (2011), Soil and Water Assessment Tool Theoretical Documentation Version 2009. Texas Water Resources Institute Technical Report , 406 pp, Texas A\&M University; Texas.

Ngo T.S., Nguyen D.B. and Rajendra P.S. (2015), Effect of land use change on runoff and sediment yield in Da River Basin of Hoa Binh province, Northwest Vietnam, Journal of Mountain Science, 12(4), 1051-1064.

Pechlivanidis I.G., Jackson B., McIntyre N. and Wheater H.S. (2011), Catchment scale hydrological modelling: A review of model types, calibration approaches and uncertainty analysis methods in the context of recent developments in technology and applications, Global NEST Journal, 13, 193-214.

Pechlivanidis I.G., Olsson J., Sharma D., Bosshard T. and Sharma K.C. (2015), Assessment of the climate change impacts on the water resources of the Luni region, India, Global NEST Journal, 17, 29-40.

Pettitt A.N. (1979), A non-parametric approach to the change-point problem, Applied Statistics, 28, 126-135.

Phan D.B., Wu C.C. and Hsieh S.C. (2011), Impact of climate change on stream discharge and sediment yield in northern Vietnam, Water Resources, 38(6), 827-836.

Quyen N.T.N., Lie N.D. and Loi N.K. (2015), Effect of land use change on water discharge in Srepok watershed, Central Highland, Vietnam, International Soil and Water Conservation Research, 2(3), 74-86.

Raghavan S.V., Tue V.M. and Shie-Yui L. (2014), Impact of climate change on future streamflow in the Dakbla river basin, Journal of Hydroinformatics, 16(1), 231-244.

Tan M.L., Ibrahim A.L., Yusop Z., Duan Z. and Ling L. (2015), Impacts of land-use and climate variability on hydrological components in the Johor River Basin, Malaysia, Hydrological Sciences Journal, 60(5), 873-889.

Tu T. (2009), Combined impact of climate and land-use changes on streamflow and water quality in eastern Massaschusetts, USA, Journal of Hydrology, 379, 268-283.

Wang R., Kalin L., Kuang W. and Tian H. (2014), Individual and combined effects of land use/cover and climate change on Wolf Bay watershed streamflow in Southern Alabama, Hydrological Processes, 28, 5530-5546.

Wang S., Kang S., Zhang L. and Li F. (2008), Modeling hydrological response to different land-use and climate change scenarios in the Zamu River Basin of northwest China, Hydrological Processes, 22, 2502-2510.

Wang W., Shao Q., Yang T., Peng S., Xing W., Sun F. and Luo Y. (2013), Quantitative assessment of the impact of climate variability and human activities on runoff changes: a case study in four catchments of the Haihe River basin, China, Hydrological Processes, 27(8), 1158-1174.

Wetterhall F., Graham L.P., Andréasson J., Rosberg J. and Yang W. (2011), Using ensemble climate projections to assess probabilistic hydrological change in the Nordic region, Natural Hazards and Earth System Sciences, 11, 2295-2306, doi:10.5194/nhess-11-2295-2011.

Zhang D., Liu X. and Liu C. (2013), Responses of runoff to climatic variation and human activities in the Fenhe River, China, Stochastic Environmental Research and Risk Assessment, 27, 1293-1301. 